\title{
МАРКЕТИНГОВЕ ДОСЛІДЖЕННЯ ЛІКАРСЬКИХ ЗАСОБІВ, ЩО ВИКОРИСТОВУЮТЬСЯ ДЛЯ НАДАННЯ КВАЛІФІКОВАНОЇ МЕДИЧНОЇ ДОПОМОГИ ХВОРИМ ВІЙСЬКОВОСЛУЖБОВЦЯМ ІЗ ХРОНІЧНИМИ ЗАХВОРЮВАННЯМИ ДИХАЛЬНИХ ШЛЯХІВ
}

\author{
О.В. Плєшкова 1 , О.В. Бєлозьорова' ${ }^{1}$ А.В. Нікітюк² \\ 1Украӥнська військово-медична академія, м. Київ, Украӥна \\ 271 військовий мобільний госпіталь, м. Київ, Украӥна
}

Вступ. 3 огляду на провідне місце хронічних захворювань дихальних шляхів у захворюваності військовослужбовців (80-90\% від загальної кількості інфекційних захворювань на рік) все більшого медикосоціального значення набуває якість надання медичної допомоги та її оптимізація. Відмічається швидкий розвиток толерантності різних збудників до існуючих антибактеріальних засобів, алергічні та інші побічні ефекти при застосуванні лікарських засобів. Збільшення арсеналу лікарських засобів на ринку України не сприяє суттєвому покращанню ситуації щодо захворюваності органів дихання у військовослужбовців.

Мета. Провести маркетинговий аналіз вітчизняного ринку лікарських засобів, які використовуються для надання кваліфікованої медичної допомоги хворим військовослужбовцям із хронічним бронхітом.

Матеріали та методи. Матеріалами дослідження була база даних зареєстрованих в Україні ЛЗ, представленої на офіційному сайті Державної установи "Державний експертний центр» Міністерства охорони здоров'я України. Для проведення дослідження ЛЗ використовували системно-оглядовий, бібліографічний, ретроспективний, маркетинговий аналізи.

Результати. Встановлено, що за частотою застосування при лікуванні військовослужбовців із хронічним бронхітом серед загальної кількості ЛЗ антибактеріальні засоби для системного використання займають провідне третє місце за кількістю міжнародних непатентованих назв та перше місце у світі. Проведений маркетинговий аналіз вітчизняного фармацевтичного ринку антибактеріальних засобів для надання кваліфікованої медичної допомоги хворим військовослужбовцям із хронічним бронхітом засвідчив пріоритетні позиції за широтою асортименту ЗАТ «Фармацевтична фірма «Дарниця», ТОВ «ФК «Здоров'я», корпорації «Артеріум», переважна кількість яких таблетованої форми. У групі противірусних засобів попит у лікуванні хронічного бронхіту має інозит пронабекс імпортного виробництва, домінують тверді лікарські форми таблетки. Переважна частина муколітичних засобів є препаратами іноземних фармацевтичних компаній з 10 країн світу, лідерами серед країн-виробників є Німеччина та Індія.

Висновки. Досліжжена номенклатура лікарських засобів, які використовуються для надання кваліфікованої медичної допомоги хворим військовослужбовцям із хронічним бронхітом, представлених на вітчизняному фармацевтичному ринку. Вивчена географія постачальників лікарських засобів визначених груп. Основна частина представленого на ринку асортименту лікарських засобів є препаратами іноземних фармацевтичних компаній. Встановлено, що домінуючими лікарськими формами у досліджуваних групах лікарських засобів на сучасному ринку є таблетки.

Ключові слова: військовослужбовці, кваліфікована медична допомога, лікарські засоби, маркетинговий аналіз, антибіотикотерапія.

Вступ. Захворювання органів дихальної системи $€$ найрозповсюдженішою нозологією серед військовослужбовців. Досвід минулих років показав, що саме якісне та своєчасне надання необхідного виду медичної допомоги $\epsilon$ одним із важливих факторів збереження життя та здоров'я військовослужбовців. Правильно розроблений та впроваджений перелік лікарських засобів (ЛЗ) для лікування хворих із хронічним бронхітом (ХБ) дозволить виключити недостатньо ефективні препарати та створити клінічно обгрунтовані схеми лікування, що сприятиме зменшенню кількості смертельних випадків, скороченню тривалості лікування та швидкому поверненню військовослужбовців до повної боєготовності $[1,2,3]$. У зв'язку з цим необхідно дослідити фармацевтичний ринок лікарських засобів, які використовуються для надання кваліфікованої медичної допомоги хворим військовослужбовцям із хронічними захворюваннями дихальних шляхів, що і стало метою нашого дослідження.

Матеріали та методи дослідження. Матеріалами дослідження були бази даних зареєстрованих в Україні ЛЗ, представленої на офіційному сайті Державної установи «Державний експертний центр» Міністерства охорони здоров'я України. Для проведення дослідження ЛЗ використовували системно- 
оглядовий, бібліографічний, ретроспективний, маркетинговий аналізи, експертних оцінок.

Результати дослідження та їх обговорення. Тактика лікування хворих на ХБ викладена у положенні Глобальної стратегії (ініціативи) 3 діагностики менеджменту та профілактики хронічного обструктивного захворювання легень - GOLD [4]. В Україні надання медичної допомоги при ХБ регламентовано уніфікованим клінічним протоколом, відповідно до якого у лікуванні хворих з ХБ використовуються стимулятори дихання (R07AB), протикашльові препарати (R05DB), відхаркувальні засоби (R05CA); Л3, що призначаються у випадках бронхіальної обструкції:

бронхорозширювальні (бронхолітичні) лікарські засоби (R03A), протиалергічні, десенсибілізуючі засоби (R01A), відхаркувальні (R05C); Л3, що застосовуються при набряку легень (серцеві глікозиди - C01А, гангліоблокатори - С02B, судинорозширювальні засоби міотропної дії C01D, адреноблокатори - C02C; нейролептики N05A; протиалергічні Л3 (препарати глюкокортикоїдів - Н02А, протигістамінні Л3 R06A, інгібітори фібринолізу - B02АA; антибактеріальні засоби для системного застосування: тетрацикліни - J01AA, беталактамні антибіотики - J01C, J01D, макроліди, лінкозаміди і стрептограми - J01F, аміноглікозиди - J01G, антибактеріальні засоби групи хінолінів - J01M, карбапенеми i монобактами - J01DH, J01DF, пробіотики, пребіотики - A07FA05, A07FA51 [5, 6].
Станом на січень 2021 року українська фармацевтична промисловість виробляє близько 3000 препаратів на ринку України, які необхідні для надання кваліфікованої медичної допомоги хворим військовослужбовцям при захворюваннях органів дихання, а саме ХБ. Вітчизняні фармацевтичні підприємства виробляють ЛЗ практично в усіх формах (твердих, рідких, суспензійних, ампульних, порошкоподібних тощо) [7].

За даними проаналізованих джерел інформації серед загальної кількості ЛЗ антибактеріальні засоби для системного використання займають провідне третє місце за кількістю міжнародних непатентованих назв та перше місце у світі за широтою застосування при лікуванні хворих із ХБ.

У більшості досліджень доведено, що антибактеріальна терапія необхідна у всіх випадках лікування незалежно від етіології ХБ. Тривале застосування антибіотиків може викликати ряд ускладнень, таких як діарея, унаслідок росту в кишечнику Clostridium difficile, що виникає вже через 24 год після антибактеріальної терапії [8, 9].

Спираючись на дані фахової наукової літератури та результатів аналізу нормативних документів щодо медикаментозного забезпечення хворих із ХБ нами сформовані досліджувані переліки антибіотиків для надання кваліфікованої терапевтичної допомоги хворим військовослужбовцям, які входять до Державного формуляру ЛЗ та дозволені до використання в 3С України (табл. 1).

Таблиця 1

Перелік препаратів групи антибіотиків, що входять до Державного формуляру ЛЗ та дозволені до використання в ЗС України

\begin{tabular}{|c|c|c|}
\hline Код & Міжнародна назва & Форма випуску \\
\hline T2AA6000Y & Антибіотики групи пеніциліну та цефалоспорину & \\
\hline T2A00400Y & Бензилпеніцилін & флакони 1,0 \\
\hline T2A00460Y & Біцилін - 5 & флакони 1500000 ОД \\
\hline T2A00255Y & Амоксіцилін + кислота клавуланова & флакони 1,0 + 0,2 \\
\hline T2A00250Y & Амоксіцилін + кислота клавуланова & таблетки $0,5+0,125$ \\
\hline T2A00260Y & Амоксіцилін & таблетки 0,5 \\
\hline T2A03605Y & Цефазолін & флакони 1,0 \\
\hline T2A03630Y & Цефтріаксон & флакони 1,0 \\
\hline T2AA6400Y & Антибіотики різних груп & \\
\hline T2A03690Y & Ципрофлоксацин & флакони 0,2 \% - 100,0 \\
\hline T2A03695Y & Ципрофлоксацин & таблетки 0,5 \\
\hline T2A00085Y & Азітроміцин & таблетки 0,5 \\
\hline T2A02467Y & Офлоксацин & флакони 0,3 \% - 5,0 \\
\hline T2AA6600Y & Сульфаніламідні препарати & \\
\hline T2A02975Y & Декаметоксин & таблетки 0,0002 \\
\hline T2A03130Y & Сульфацетамід & флакони $30 \%-10,0$ \\
\hline
\end{tabular}


Аналіз листків призначень історій хвороб військовослужбовців із ХБ, надав нам змогу визначити перелік антибіотиків, які найчастіше використовуються при даній нозології (табл. 2).

Таблиця 2

Групи антибіотиків, які використовуються при лікуванні військовослужбовців із ХБ

\begin{tabular}{|c|c|c|c|}
\hline $\begin{array}{l}\text { ATC- } \\
\text { код }\end{array}$ & Група & $\begin{array}{c}\text { Міжнародна } \\
\text { непатентована назва }\end{array}$ & $\begin{array}{c}\text { Tоргові назви } \\
\text { (представники) }\end{array}$ \\
\hline J01DC & Цефалоспорини другої генерації & Цефуроксим & Зинаце $\phi^{\text {тм }}$ \\
\hline \multirow[t]{9}{*}{ J01DD } & \multirow[t]{9}{*}{ Цефалоспорини третьої генерації } & Цефіксим & Фікс \\
\hline & & Цефотаксим & Кімаце $\phi^{\circledR}$ \\
\hline & & Цефоперазон & Гепацеф \\
\hline & & Цефоперазон, комбінації & Гепацеф Комбі \\
\hline & & Цефтазидим & Тулізид \\
\hline & & Цефподоксим & Цеподем \\
\hline & & Цефтибутен & Цедекс ${ }^{\circledR}$ \\
\hline & & Цефтріаксон, комбінації & Сульбактомакс \\
\hline & & Цефотаксим, комбінації & Такстам \\
\hline \multirow[t]{3}{*}{ J01DE } & \multirow[t]{3}{*}{ Цефалоспорини четвертої генерації } & Цефепім & Квартацеф \\
\hline & & Цефпіром & Цефпіром \\
\hline & & Цефепім, комбінації & Потентокс \\
\hline \multirow[t]{5}{*}{ J01C1R } & \multirow[t]{5}{*}{$\begin{array}{l}\text { Комбінації пеніциліну, у тому числі } 3 \\
\text { інгібіторами бета-лактамаз }\end{array}$} & $\begin{array}{ll}\text { Ампіцилін } & \text { та } \\
\text { інгібіторферменту } & \end{array}$ & Уназин \\
\hline & & $\begin{array}{l}\text { Амоксицилін та інгібітор } \\
\text { ферменту }\end{array}$ & Амоксиклав ${ }^{\circledR}$ \\
\hline & & $\begin{array}{l}\text { Тікарциллін та інгібітор } \\
\text { ферменту }\end{array}$ & Тиментин \\
\hline & & $\begin{array}{l}\text { Піперацилін та інгібітор } \\
\text { ферменту }\end{array}$ & Зоперцин \\
\hline & & Комбінація пеніцилінів & Вампілокс \\
\hline \multirow[t]{4}{*}{ J01GB } & \multirow[t]{4}{*}{ Інші аміноглікозиди } & Гентаміцин & Гентаміцин-К \\
\hline & & Канаміцин & Канаміцину сульфат \\
\hline & & Амікацин & Флекселіт \\
\hline & & Нетилміцин & Нетроміцин $^{\circledR}$ \\
\hline \multirow[t]{10}{*}{ J01MA } & \multirow[t]{10}{*}{ Фторхінолони } & Офлоксацин & ОфлоГексал ${ }^{\circledR}$ \\
\hline & & Ципрофлоксацин & Цифран OD \\
\hline & & Перфлоксацин & Юнікпеф \\
\hline & & Норфлоксацин & Ноліцин \\
\hline & & Ломефлоксацин & Ломадей \\
\hline & & Спарфлоксацин & Спарфло \\
\hline & & Левофлоксацин & Флексид ${ }^{\circledR}$ \\
\hline & & Моксифлоксацин & Авелокс \\
\hline & & Геміфлоксацин & Фактів \\
\hline & & Гатифлоксацин & Бігафлон ${ }^{\circledR}$ \\
\hline \multirow[t]{2}{*}{ J01XA } & \multirow[t]{2}{*}{ Глікопептидні антибіотики } & Ванкоміцин & Ванкум \\
\hline & & Тейкопланін & Таргоцид \\
\hline \multirow[t]{3}{*}{ J01XD } & \multirow[t]{3}{*}{ Похідні імідазолу } & Метронідазол & 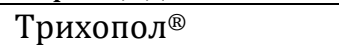 \\
\hline & & Тінідазол & Фазижин \\
\hline & & Орнідазол & Орнізол \\
\hline \multirow[t]{6}{*}{ J01FA } & \multirow[t]{6}{*}{ Макродіди } & Кларитроміцин & Фромілід \\
\hline & & Азитроміцин & Азитрал 250 \\
\hline & & Еритроміцин & Альтроцин-S \\
\hline & & Мідекаміцин & ${\text { Макропен }{ }^{\circledR}}$ \\
\hline & & Рокситроміцин & Роксилід \\
\hline & & Джозаміцин & Вільпрафен ${ }^{\circledR}$ \\
\hline \multirow[t]{2}{*}{ J01DH } & \multirow[t]{2}{*}{ Карбапенеми } & Меропенем & Меронем \\
\hline & & Ертапенем & Інванз ${ }^{\circledR}$ \\
\hline \multirow[t]{2}{*}{ J01DH } & \multirow[t]{2}{*}{ Карбапенеми } & Дорипенем & Дорібакс \\
\hline & & Іміпенем & Тієнам ${ }^{\circledR}$ \\
\hline
\end{tabular}


Серед групи антибіотиків найбільшу кількість найменувань пропонують вітчизняного виробництва «Фармацевтична фірма «Дарниця» (25 «Фармацевтична фірма «Дарниця» (25 3AT найменувань ЛЗ) та ТОВ «ФК «Здоров'я» $(20$ найменувань Л3). Загалом ці виробники постачають третину препаратів. Крім того, значний обсяг продукції на внутрішній фармацевтичний ринок надходить від корпорації «Артеріум» (Київ) - 18 найменувань ЛЗ та ЗАТ «НВЦ «Борщагівський ХФЗ» 13 найменувань ЛЗ. Отже, наведені фірми-виробники постачають на внутрішній фармацевтичний ринок майже половину від загального асортименту вітчизняних лікарських препаратів (рис. 1).

$$
\begin{array}{r}
\text { Інші } \\
\text { тОВ "Фарма Старт" } \\
\text { ВАТ "Лубнифарм" } \\
\text { ВАТ "Вітаміни" } \\
\text { тОВ "Астрафарм" } \\
\text { ВАТ "Червона зірка" } \\
\text { TОВ "Юрія-Фарм" } \\
\text { ЗАТ "Лекхім-Харків" } \\
\text { ТОВ "Фарма Лайф" } \\
\text { ТОВ "Авант" } \\
\text { ТОВ ФК "Здоров'я" }
\end{array}
$$

ЗАТ ФФ "Дарниця" Корпорація "Артеріум"

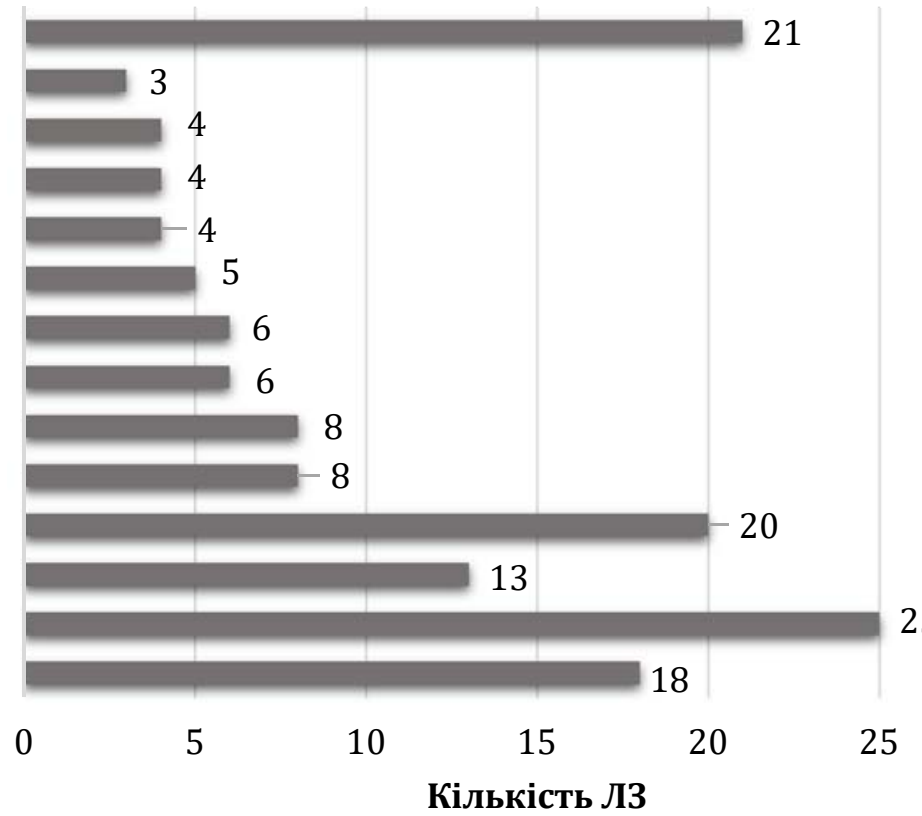

Рисунок 1. Фірми виробники вітчизняних антибіотиків на фармацевтичному ринку

На фармацевтичний ринок України імпортуються антибіотики 95 іноземних фірмвиробників з 30 країн світу, серед яких позицію лідера за обсягом постачання посідає Індія, друге місце належить Словенії, третє - Великобританії, незначний внесок фармацевтичного ринку України складають Македонія, Італія, Литва та Ізраїль (рис. 2).

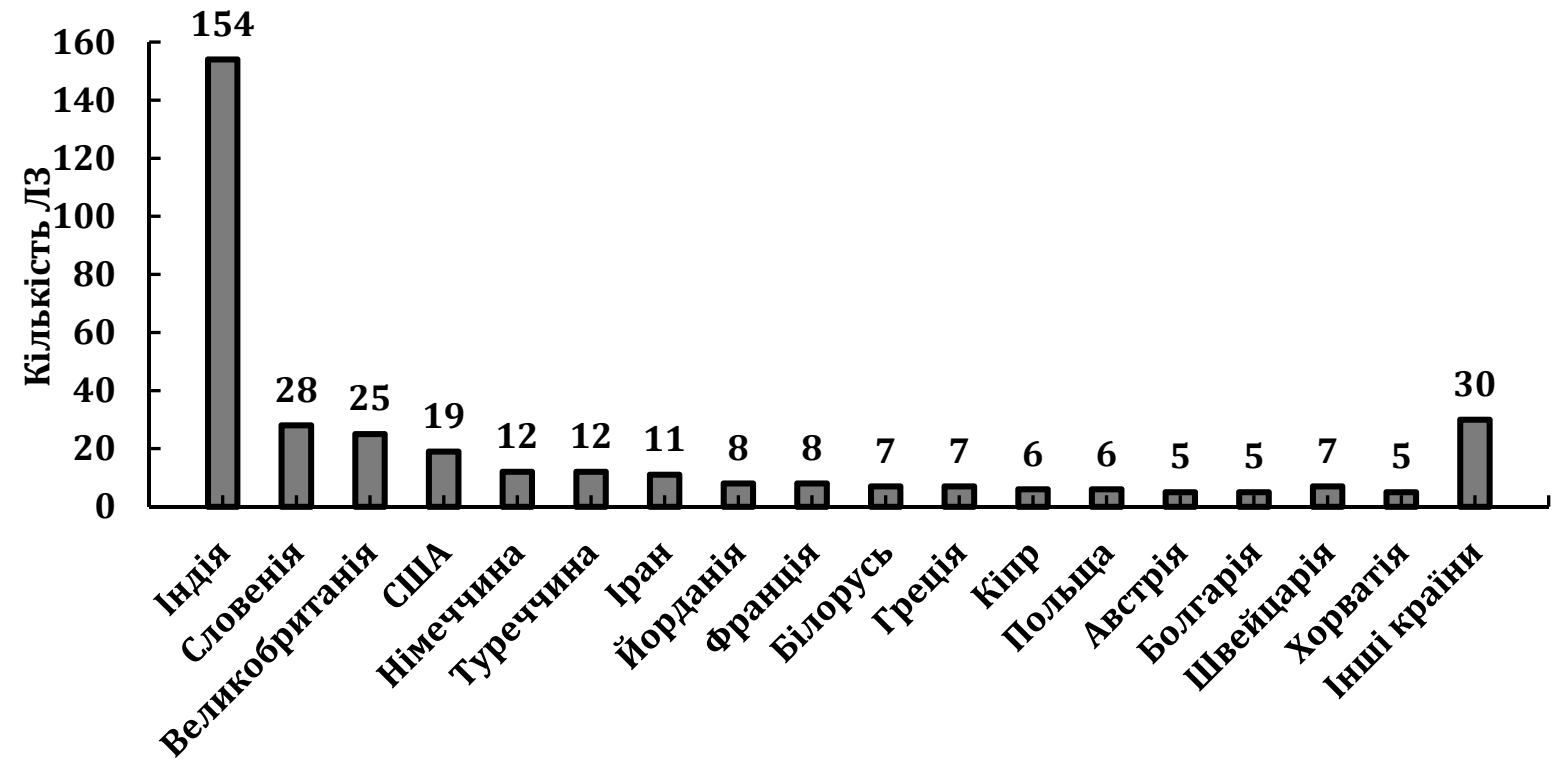

\section{Іноземні краӥни-постачальники} України

Рисунок 2. Іноземні країни-постачальники АН на вітчизняний фармацевтичний ринок 
На вітчизняному фармацевтичному ринку антибактеріальні засоби представлені великою кількістю лікарських препаратів та ЛФ як українського виробника, так і іноземних фірм-виробників.

При проведенні аналізу ЛФ антибіотиків встановлено, що значний сегмент ринку зазначеної групи препаратів займають таблетовані ЛФ (рис. 3). Крім того, аналіз листів призначень хворих військовослужбовців показав, що саме таблетовані ЛФ найчастіше призначаються 3 метою надання кваліфікованої терапевтичної медичної допомоги хворим із ХБ.

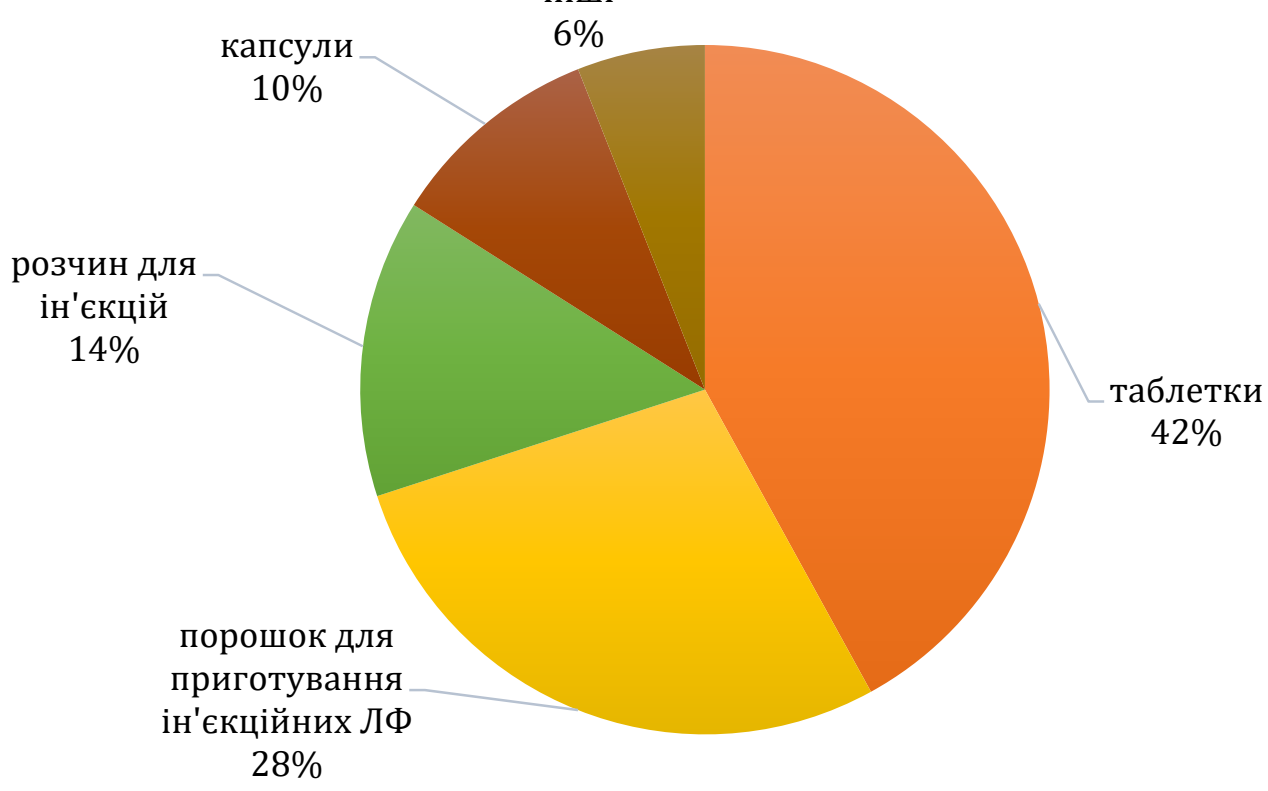

Рисунок 3. ЛФ антибактеріальних засобів для системного використання на вітчизняному фармацевтичному ринку для лікування ХБ

Наступною важливою групою препаратів, які використовуються для лікування ХБ є противірусні препарати.

Вибір раціональної противірусної терапії ХБ визначається існуючими рекомендаціями і нормативними документами зареєстрованих та дозволених до застосування ЛЗ. На сьогодні існує невелика кількість специфічних противірусних засобів. За даними Державного експертного центру M03 України у 2018 році кількість зареєстрованих противірусних препаратів збільшилась близько як у 7 разів. На фоні збільшення зареєстрованих торгових позицій у порівнянні з 2010 роком спостерігається збільшення фірм-виробників, що представляли противірусні препарати на ринку України.

$$
\text { Аналіз динаміки кількості }
$$
зареєстрованих противірусних препаратів в Україні за 2010-2018 рр. представлено на рис. 4.

$$
\text { У порівнянні } 32018 \text { р. в } 2020 \text { p. }
$$

спостерігається значне зростання кількості зареєстрованих ЛЗ. Так, у 2018 р. фірмамивиробниками було представлено 41 противірусний ЛЗ для надання кваліфікованої терапевтичної допомоги хворим військовослужбовцям із ХБ, а протягом наступних двох років їх кількість збільшилась майже у два рази.

Якісний склад препаратів, що були зареєстровані з 2010 по 2020 рр., представлені переважно монокомпонентними Л3, що містять озельтамівір, занамівір, інозин пронабекс, кагоцел, тилорон, ацикловір, римантадин $[10,11]$.

Крім того, аналіз проведеного опитування показав, що найбільший попит у лікуванні ХБ має інозит пронабекс імпортного виробництва, вітчизняний новірин посів третє місце. Наведені препарати найчастіше використовуються для лікування хронічного бронхіту та користуються попитом серед спеціалістів-терапевтів та лікарів загального профілю (рис. 5). 


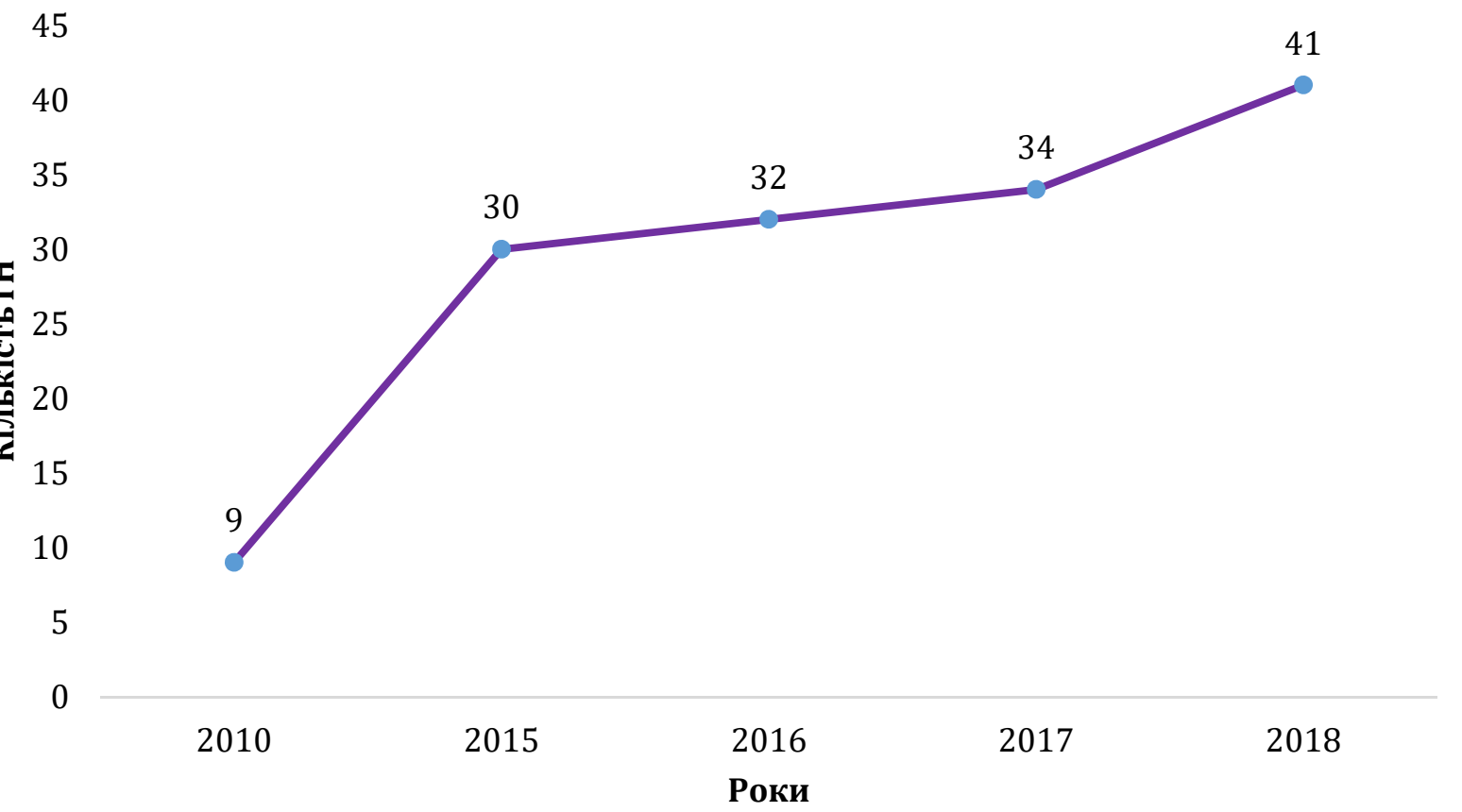

Рисунок 4. Аналіз динаміки кількості зареєстрованих противірусних препаратів для лікування ХБ

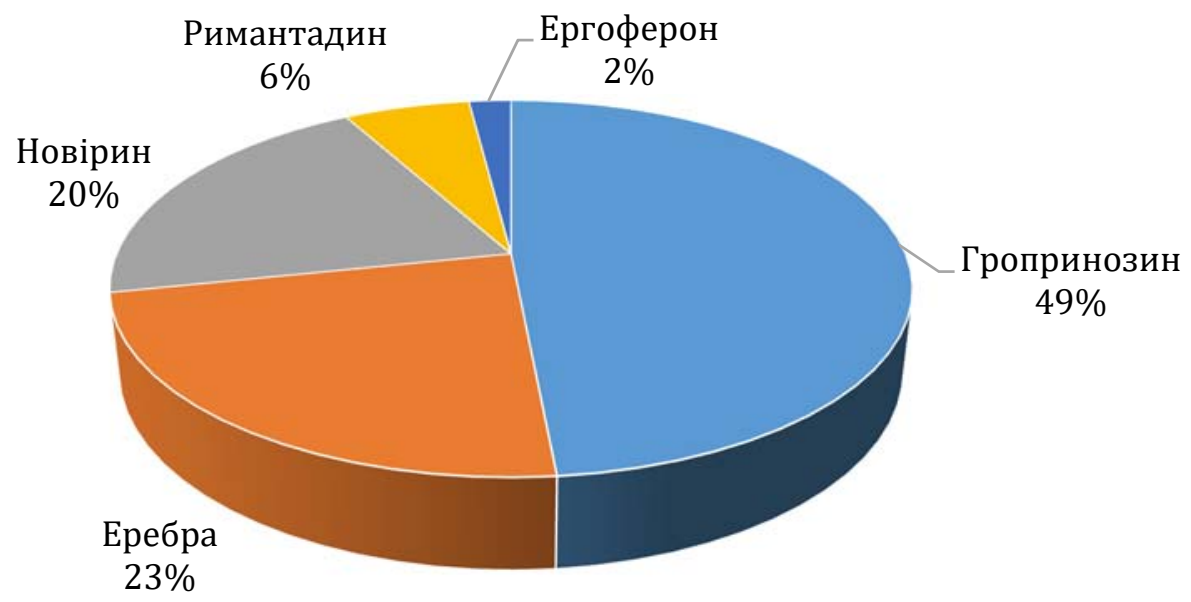

Рисунок 5. ТОП-5 противірусних препаратів (за даними анкетного опитування)

Перелік ЛЗ для противірусної терапії хворим військовослужбовцям із ХБ за Державним формуляром лікарських засобів наведений у таблиці 3.

Таблиця 3

Перелік противірусних ЛЗ, які внесені до Державного формуляру та включенні до медикаментозного постачання ЗС України

\begin{tabular}{|c|c|c|}
\hline Код & $\begin{array}{l}\text { Противірусні } \\
\text { препарати }\end{array}$ & Форма випуску \\
\hline T2A00367Y & Ацикловір & флакони 0,5 \\
\hline T2A01881Y & Ацикловір & таблетки 0,8 \\
\hline T2A00550Y & Валацикловір & таблетки 0,5 \\
\hline T2A00650Y & Занамівір & порошок для інгаляцій по 0,005 \\
\hline T2A02376Y & Озельтамівір & капсули 0,075 \\
\hline T2A02875Y & Рибавірин & таблетки 0,2 \\
\hline T2A02776Y & Софосбувір & капсули 0,4 \\
\hline
\end{tabular}


За результатами аналізу сукупності противірусних препаратів стосовно лікарських форм за аналізом листів призначень встановлено, що безумовне домінування на ринку противірусних препаратів мають препарати у твердих ЛФ, а саме таблетки (рис. 6).

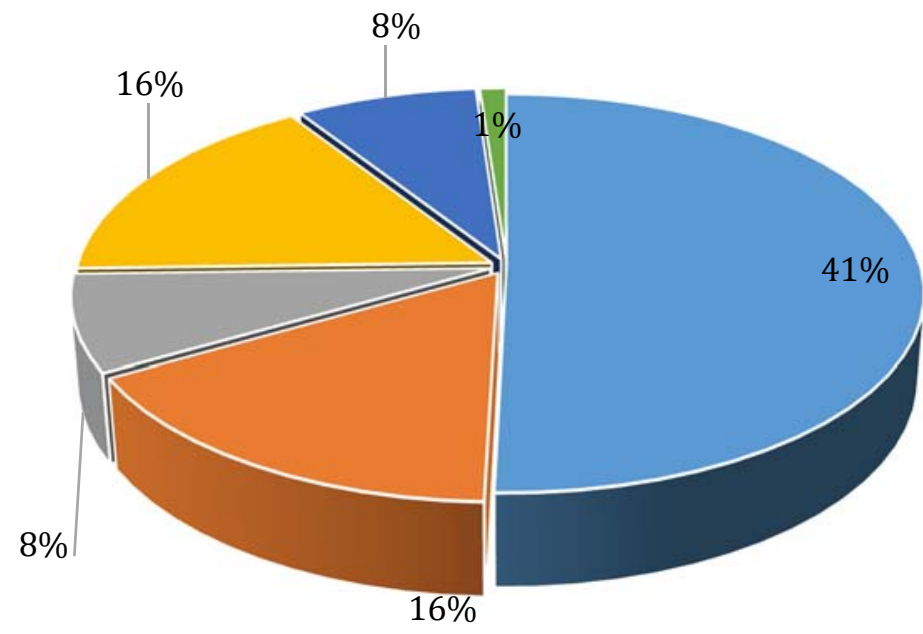

- Таблетки

- Порошки для приготування ін'єкційних розчинів

- Розчини для ін'єкцій

- Капсули

- Порошки для внутрішнього застосування

- Інші

Рисунок 6. ЛФ противірусних препаратів за даними листів призначень для військовослужбовців з ХБ

Так, питома вага ЛЗ у вигляді капсул, таблеток, порошків для перорального застосування становить у сумі $73 \%$.

Не менш важливе значення в комплексній терапії ХБ має лікування такого симптому як кашель. За даними офіційного сайту Державного експертного центру М03
України станом на 01.01.2021 р. в Україні було зареєстровано $105 \mathrm{TH}$, які представлені різними ЛФ з урахуванням їх дозування. Основна частина представленого на ринку асортименту муколітичних засобів $\epsilon$ препаратами іноземних фармацевтичних компаній (табл. 4).

Таблиця 4

\section{Класифікація та структура зареєстрованих (перереєстрованих) в Україні} муколітичних засобів

\begin{tabular}{|c|c|c|c|c|}
\hline $\begin{array}{l}\text { Назва } \\
\text { групи }\end{array}$ & $\begin{array}{l}\text { 5-й рівень } \\
\text { коду АТХ }\end{array}$ & Назва препаратів & Кількість ТН & $\%$ \\
\hline \multirow{9}{*}{ 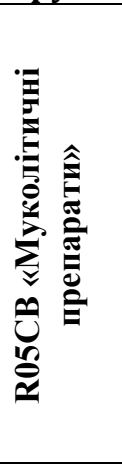 } & 01 & Ацетилцистеїн & 30 & 28,56 \\
\hline & 02 & Бромгексин & 10 & 9,51 \\
\hline & 03 & Карбоцистеїн & 6 & 5,71 \\
\hline & 06 & Амброксол & 50 & 47,62 \\
\hline & 10 & Комбінації & 4 & 3,80 \\
\hline & 13 & $\begin{array}{l}\text { Дорназа альфа } \\
\text { (дезоксирибонуклеаза) }\end{array}$ & 1 & 1,00 \\
\hline & 15 & Ердостеїн & 2 & 1,90 \\
\hline & 52 & Бромгексин, комбінації & - & - \\
\hline & 56 & Амброксол, комбінації & 2 & 1,90 \\
\hline \multicolumn{3}{|l|}{ Всього } & 105 & 100 \\
\hline
\end{tabular}

Аналіз даних наведених в табл. 4 показав, що препарати ацетилцистеїну та амброксолу на фармацевтичному ринку України складають понад $76 \%$ всіх зареєстрованих препаратів, а відсутні у вітчизняному асортименті Л3 препарати бромгексину у комбінації. Із загальної кількості ТН муколітичних засобів 
українськими підприємствами-виробниками представлено 39 асортиментних позицій, що складає понад $37 \%$ загальної кількості досліджуваних препаратів. За кількістю репрезентованих препаратів номенклатуру вітчизняного фармацевтичного ринку забезпечують 19 фірм - виробників, лідерами $\epsilon$ такі компанії, як: ТОВ "Фармацевтична компанія "Здоров'я" (8 препаратів), ЗАТ НВЦ "Борщагівський ХФЗ» (4 препарати).

Переважна частина препаратів даної групи постачається іноземними фірмамивиробниками з 10 країн світу (рис. 7).
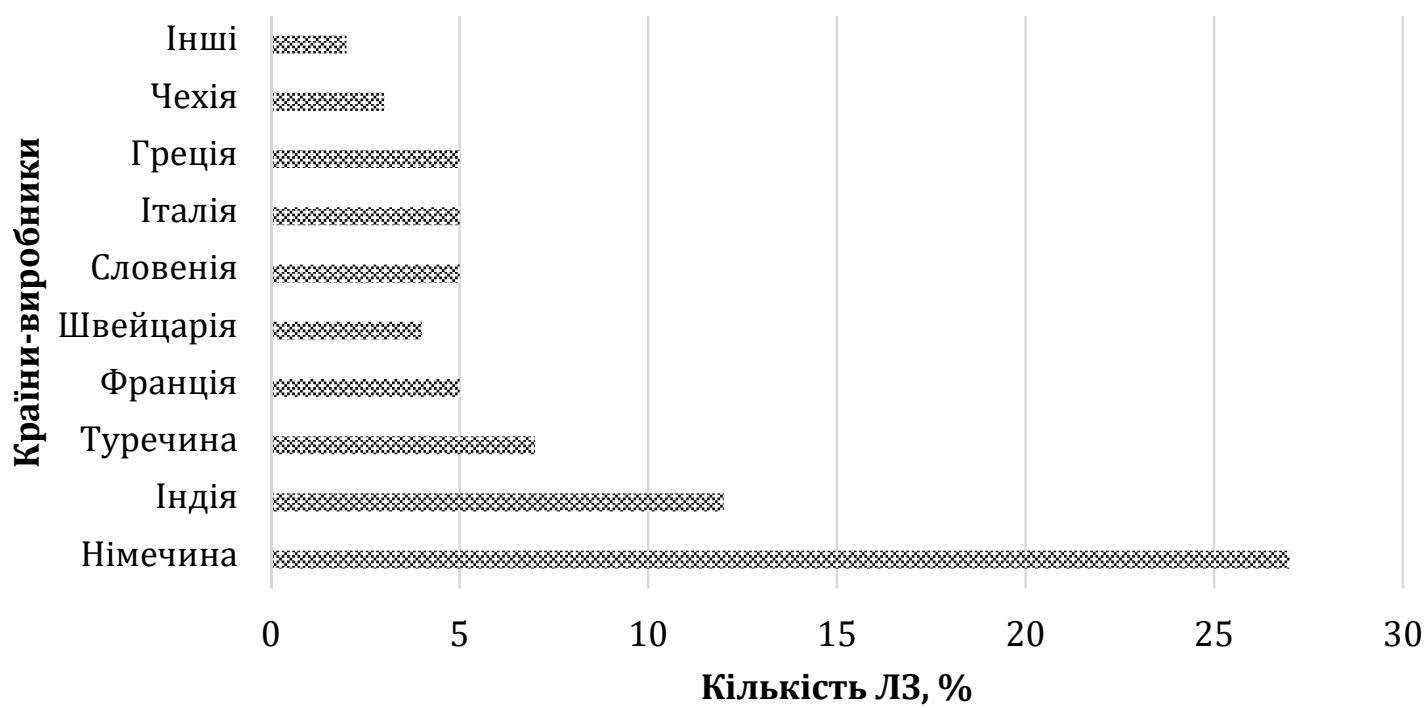

Рисунок 7. Ранжування країн-виробників в залежності від обсягу постачання на український фармацевтичний ринок муколітичних препаратів

Як видно 3 рис. 7 , безумовними лідерами серед країн-постачальників $\epsilon$ Німеччина та Індія, виробники якої зареєстрували 27 та $11 \mathrm{TH}$ муколітичних препаратів відповідно. Інші іноземні компанії представили на фармацевтичний ринок України від однієї до п'яти торгових назв муколітиків.
Наступним етапом стало дослідження муколітичних засобів за формою випуску. Так встановлено, що муколітичні засоби переважно поступають на ринок у вигляді пероральних, парентеральних та інших лікарських форм (рис. 8).

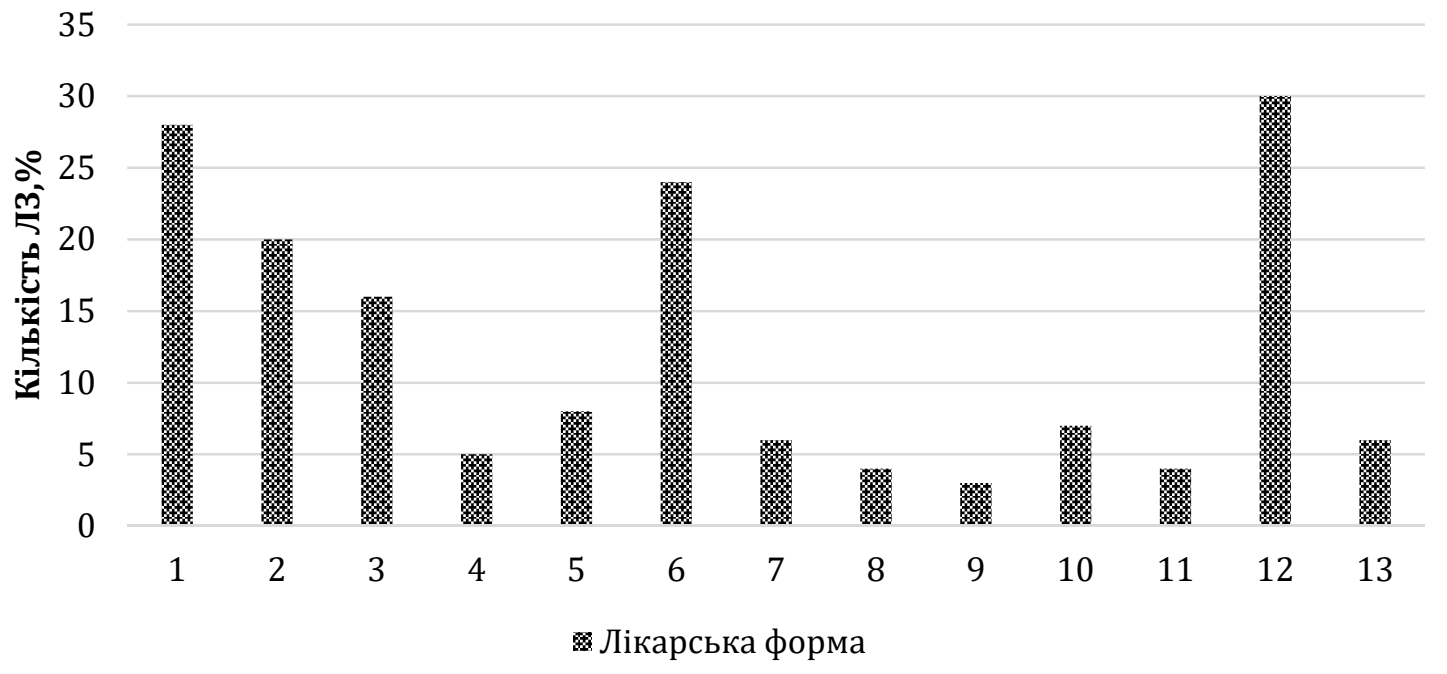

Рисунок 8. Розподіл зареєстрованих муколітичних засобів за ЛФ з урахуванням дитячих лікарських форм: 1 - таблетки; 2 - сироп; 3 - порошок для приготування орального розчину; 4 розчин для інєкцій; 5 - гранули для приготування орального розчину; 6 - капсули; 7 - розчин оральний; 8 - краплі для перорального застосування; 9 - розчин для інгаляцій; 10 - таблетки, що диспергуються; 11 - чай; 12 - пастилки; 13 - еліксир. 
Аналізуючи муколітичні препарати за частотою застосування встановлено, що лідируючу позицію займають препарати 3 групи амброксолу, друге місце 3 істотним відривом посідають препарати групи ацетилцистеїну. Слід зазначити, що препарати для перорального прийому (таблетки, розчини для перорального прийому), які переважно призначені для лікування ХБ,

\section{Висновки}

1. Встановлено, що найбільш вживаними при наданні кваліфікованої терапевтичної допомоги військовослужбовцям із ХБ серед багатьох фармакологічних груп ЛЗ є група антибактеріальних засобів для системного використання, противірусних ЛЗ та муколітиків.

2. При проведенні дослідження вітчизняного ринку антибактеріальних засобів для системного використання визначено, що лідером серед фармацевтичних виробників України є Корпорація «Артеріум», ТОВ «Київмедпрепарат» (Київ) та ЗАТ «Фармацевтична фірма «Дарниця», серед країн перше місце по виробництву антибіотиків для лікування ХБ займає Індія. При проведенні аналізу антибіотиків за видом ЛФ встановлено, що значний сегмент ринку

\section{Література}

1. Клячкина И.Л. Хронический бронхит: фармакотерапевтический фокус на гиперсенситивный компонент кашля. Consilium Medicum. 2020. T. 22. № 3. C. 46-54. DOI: https://doi.org/10.26442/20751753.2020.3.200055.

2. Соціальна медицина та організація здоров'я: підручник / за заг. ред. Ю.В. Вороненка, В.Ф. Москаленка. Тернопіль: Укрмедкнига, 2015. 332 с.

3. National Institute for Health and Care Exellence. Multimorbidity: clinical assessment and management, in press. 2016.2 URL: http://www.nice.org.uk/guidance/indevelopment/gid -cgwave0704/document (дата звернення: 01.09.2021).

4. Global strategy for the diagnosis, management and prevention of chronic obstructive pulmonary disease (report 2018), 142 p. URL: https://goldcopd.org/wp-

content/uploads/2017/11/GOLD-2018-v6.0-FINALrevised-20-Nov WMS.pdf (дата звернення: 01.09.2021).

5. Сучасні підходи щодо раціонального використання лікарських засобів в умовах військових лікувальних закладів: навч. посіб. / А.Г. Голуб, Н.І. Хомутецька, Р.Л. Притула та ін. Київ: УBMA, 2004. $54 \mathrm{c}$.

\section{References}

1. Klyachkina, I.L. (2020). Khronicheskiy bronkhit: farmakoterapevticheskiy fokus na gipersensitivnyy komponent kashlya. Consilium Medicum, 22(3), 46-54. doi: $10.26442 / 20751753.2020 .3 .200055$. [In Russian]. складали лише 45 \% в досліджуваній групі муколітичних препаратів. Всі призначені муколітичні препарати входять до переліку ЛЗ дозволених до використання в закладах охорони здоров'я МО України для надання кваліфікованої терапевтичної допомоги хворим військовослужбовцям із хронічним бронхітом.

зазначеної групи препаратів займають таблетовані ЛФ (42\%).

3. За результатами аналізу сукупності противірусних препаратів стосовно виду ЛФ встановлено, що безумовне домінування на ринку противірусних препаратів мають препарати у твердих ЛФ, а саме таблетки (41 $\%)$.

4. За кількістю муколітичних ЛЗ номенклатуру вітчизняного фармацевтичного ринку забезпечують 19 фірм-виробників, лідерами серед яких є ТОВ "Фармацевтична компанія "Здоров'я" та ЗАТ НВЦ "Борщагівський ХФЗ", серед країнпостачальників безумовними лідерами $\epsilon$ Німеччина та Індія. При дослідженні муколітиків за формою випуску встановлено, що муколітичні засоби переважно поступають на ринок у вигляді таблеток та пастилок.

6. Стефанюк М.Ф. Морфофункціональний стан бронхів, зміни загального імунітету та неспецифічного клітинного захисту легень при повторних бронхопневмоніях у військовослужбовців строкової служби: автореф. дис... канд. мед. наук: 14.01.27. К., 1999. 18 с.

7. Ukraine healthcare and pharmaceutical industries overview. URL: http://igar.ua/eng/wpcontent/uploads/2015/11/Healthcare-and-

PharmaIndustries-Overview-2015.pdf

(дата звернення: 15.07.2021).

8. Страчунский Л.С., Белоусов Ю.Б., Козлов С.Н. Антибактериальная терапія: навч.посіб. М., 2000. $191 \mathrm{c}$.

9. Антибіотики (властивості, застосування, взаємодія): навч. посіб. / за ред. К.А. Посохова, О.П. Вікторова. Тернопіль: ТДМУ, 2005. 296 с.

10. Компендиум 2010. Лекарственные препараты / за ред. В.М. Коваленка, О.П. Вікторова. К.: МОРІОН, 2010. $2240 \mathrm{c}$.

11. Довідник лікарських засобів України 2018 року, який містить повний перелік лікарських засобів, дозволених для застосування в Україні за станом на 01.03.2018 року URL: http://www.drlz.com.ua/ibp/ddsite.nsf/all/shli st?opendocument (дата звернення: 01.09.2021).

2. Voronenko, YU.V. \& Moskalenko, V.F. (Eds.). (2015). Sotsialna medytsyna ta orhanizatsiya zdorovya: pidruchnyk. Ternopil: Ukrmedknyha. [In Ukrainian].

3. National Institute for Health and Care Exellence. 
Multimorbidity: clinical assessment and management, in press. (2016). Retrieved from http://www.nice.org.uk/guidance/indevelopment/gid -cgwave0704/document.

4. Global strategy for the diagnosis, management and prevention of chronic obstructive pulmonary disease. (2018). Retrieved from https://goldcopd.org/wpcontent/uploads/2017/11/GOLD-2018-v6.0-FINALrevised-20-Nov_WMS.pdf

5. Holub, A.H., Khomutetska, N.I., \& Prytula, R.L. (2004). Suchasni pidkhody shchodo ratsionalnoho vykorystannya likarskykh zasobiv v umovakh viyskovykh likuvalnykh zakladiv: navch. posib. Kyyiv: UVMA. [In Ukrainian].

6. Stefanyuk, M.F. (1999). Morfofunktsionalnyy stan bronkhiv, zminy zahalnoho imunitetu ta nespetsyfichnoho klitynnoho zakhystu lehen pry povtornykh bronkhopnevmoniyakh u viyskovosluzhbovtsiv strokovoyi sluzhby. (Master's thesis). AMN Ukrayiny, In-t ftyziatriyi i pul'monolohiyi im. F. H. Yanovs'koho, Kyiv. [In Ukrainian].
7. Ukraine healthcare and pharmaceutical industries overview. (2015). Retrieved from http://igar.ua/eng/wp-

content/uploads/2015/11/Healthcare-and-

PharmaIndustries-Overview-2015.pdf.

8. Strachunskyy, L.S., Belousov, YU.B., \& Kozlov S.N. (2000). Antybakteryalnaya terapiya: prakticheskoye rukovodstvo. M. [In Russian].

9. Posokhova, K.A., \& Viktorova, O.P. (Eds.). (2005). Antybiotyky (vlastyvosti, zastosuvannya, vzayemodiya): navch. posib. Ternopil: TDMU. [In Ukrainian].

10. Kovalenko, V.M., \& Viktorova O.P. (Eds.). (2010). Kompendyum 2010. Lekarstvennye preparaty. K.: MORION. [In Ukrainian].

11. Dovidnyk likarskykh zasobiv Ukrayiny 2018 roku, yakyy mistyt povnyy perelik likarskykh zasobiv, dozvolenykh dlya zastosuvannya v Ukrayini za stanom na 01.03.2018 roku. (2018). Retrieved from http://www.drlz.com.ua/ibp/ddsite.nsf/all/shlist?ope ndocument . [In Ukrainian].

\title{
МАРКЕТИНГОВОЕ ИССЛЕДОВАНИЕ ЛЕКАРСТВЕННЫХ СРЕДСТВ, ИСПОЛЬЗУЕМЫХ ДЛЯ ОКАЗАНИЯ КВАЛИФИЦИРОВАННОЙ МЕДИЦИНСКОЙ ПОМОЩИ БОЛЬНЫМ ВОЕННОСЛУЖАЩИМ ХРОНИЧЕСКИМИ ЗАБОЛЕВАНИЯМИ ДЫХАТЕЛЬНЫХ ПУТЕЙ
}

\author{
О.В. Плешкова ${ }^{1}$, О.В. Белозёрова ${ }^{1}$, А.В. Никитюк ${ }^{2}$ \\ 1 Украинская военно-медицинская академия, г Киев, Украина \\ 271 военный мобильный госпиталь, г Киев, Украина
}

Вступление. Учитывая ведущее место хронических заболеваний дыхательных путей в заболеваемости военнослужащих (80-90\% от общего количества инфекционных заболеваний в год) все большее медико-социальное значение приобретает качество оказания медицинской помощи и ее оптимизация. Отмечается быстрое развитие толерантности различных возбудителей к существующим антибактериальным средствам, аллергические и другие побочные эффекты при применении лекарственных средств. Увеличение арсенала лекарственных средств на рынке Украины не способствует существенному улучшению ситуации по заболеваемости органов дыхания у военнослужащих.

Цель. Провести маркетинговый анализ отечественного рынка лекарственных средств, используемых для оказания квалифицированной медицинской помощи больным военнослужащим с хроническим бронхитом.

Материалы и методы. Материалами исследования была база данных зарегистрированных в Украине ЛС, представленной на официальном сайте Государственного учреждения «Государственный экспертный центр» Министерства здравоохранения Украины. Для проведения исследования рынка лекарственных средств использовали системно-обзорный, библиографический, ретроспективный, маркетинговый анализы.

Результаты. Установлено, что по частоте применения при лечении военнослужащих с хроническим бронхитом среди общего количества лекарственных средств антибактериальные средства для системного использования занимают ведущее третье место по количеству международных непатентованных названий и первое место в мире. Проведенный маркетинговый анализ отечественного фармацевтического рынка антибактериальных средств для оказания квалифицированной медицинской помощи больным военнослужащим с хроническим бронхитом показал приоритетные позищии по широте ассортимента $3 А О$ «Фармацевтическая фирма« Дарница », ООО« ФК «Здоровье», корпорации «Артериум», подавляющее количество которых таблетированной формы. В группе противовирусных средств спрос в лечении хронического бронхита имеет инозит пронабекс импортного производства, доминируют твердые лекарственные формы таблетки. Большинство муколитических средств являются препаратами иностранных фармацевтических компаний из 10 стран мира, лидерами среди стран-производителей являются Германия и Индия.

Выводы. Исследована номенклатура лекарственных средств, используемых для оказания квалифицированной медицинской помощи больным военнослужащим с хроническим бронхитом, представленных на отечественном фармацевтическом рынке. Изучена география поставщиков лекарственных средств определенных групп. Основная часть представленного на рынке ассортимента лекарственных средств являются препаратами иностранных фармацевтических компаний. Установлено, что доминирующими лекарственными формами в исследуемых группах лекарственных средств на современном рынке являются таблетки.

Ключевые слова: военнослужащие, квалифицированная медицинская помощь, лекарственные средства, маркетинговый анализ, антибиотикотерапия. 


\title{
MARKETING RESEARCH OF MEDICINES USED TO PROVIDE QUALIFIED MEDICAL CARE FOR MILITARY PATIENTS WITH CHRONIC RESPIRATORY DISEASES
}

\author{
O.V. Plieshkova1 ${ }^{1}$, 0.V. Bielozorova' ${ }^{1}$ A.V. Nikituk ${ }^{2}$ \\ ${ }^{1}$ Ukrainian military medical academy, Kyiv, Ukraine \\ 271 Military mobile hospital, Kyiv, Ukraine
}

Introduction. Given the leading place of chronic respiratory diseases in the morbidity of servicemen (80$90 \%$ of the total number of infectious diseases per year), the quality of medical care and its optimization is becoming increasingly medical and social. There is a rapid development of tolerance of various pathogens to existing antibacterial drugs, allergic and other side effects when using drugs. Increasing the arsenal of medicines on the Ukrainian market does not significantly improve the situation with regard to respiratory diseases in the military.

The purpose. Conduct a marketing analysis of the domestic market of medicines used to provide qualified medical care to servicemen with chronic bronchitis.

Materials and methods. The materials of the study were taken from a database of drugs registered in Ukraine, presented on the official website of the State Institution "State Expert Center" of the Ministry of Health of Ukraine. System-review, bibliographic, retrospective, and marketing analyzes were used to conduct the drug study.

Results. It is established that in terms of the frequency of use in the treatment of servicemen with chronic bronchitis among the total number of drugs, antibacterial agents for systemic use occupy the leading third place in the number of international non-proprietary names and first place in the world. The marketing analysis of the domestic pharmaceutical market of antibacterial drugs for the provision of qualified medical care to sick servicemen with chronic bronchitis showed priority positions in the breadth of the range of CJSC "Pharmaceutical Company" Darnytsia ", LLC" FC "Health", corporation forms. In the group of antiviral drugs in demand in the treatment of chronic bronchitis has inositol pronabex imported production, dominated by solid dosage forms of tablets. The majority of mucolytics are drugs of foreign pharmaceutical companies from 10 countries, the leaders among the producing countries are Germany and India.

Conclusions. The nomenclature of medicines was used to provide qualified medical care to sick servicemen with chronic bronchitis, presented on the domestic pharmaceutical market, has been studied. The geography of suppliers of medicines of certain groups is studied. The main part of the range of medicines presented on the market are drugs of foreign pharmaceutical companies. It has been established that the dominant dosage forms in the studied groups of drugs on the modern market are tablets.

Key words: servicemen, qualified therapeutic care, medicines, marketing analysis, antibiotic therapy.

Конфлікт інтересів відсутній.

Conflict of interest: authors have no conflict of interest to declare.

\section{Відомості про авторів:}

Плєшкова О.В. А,B,C,D - підполковник медичної служби, кандидат фармацевтичних наук, старший викладач кафедри військової фармації Української військово-медичної академії, м. Київ, Україна

Бєлозьорова О.В. А,C,D,E,F - підполковник медичної служби, кандидат фармацевтичних наук, начальник науково-організаційного відділення Української військово-медичної академії, м. Київ, Україна

Нікітюк А.В. в,С - старший лейтенант медичної служби, начальник відділення медичного постачання 71 військового мобільного госпіталю, м. Київ, Україна

\section{Сведения об авторах:}

Плешкова А.В. - подполковник медицинской службы, кандидат фармацевтических наук, старший преподаватель кафедры военной фармации Украинской военно-медицинской академии, г. Киев, Украина.

Белозерова А.В. - подполковник медицинской службы, кандидат фармацевтических наук, начальник научно-организационного отделения Украинской военно-медицинской академии, г. Киев, Украина.

Никитюк А.В. - старший лейтенант медицинской службы, начальник отделения медицинского снабжения 71 военного мобильного госпиталя, г. Киев, Украина

\section{Information about authors:}

Plieshkova O.V.A,B,C,D - Lieutenant Colonel of the Medical Service, Candidate of Pharmaceutical Sciences, Senior Lecturer of the Department of Military Pharmacy of the Ukrainian Military Medical Academy, Kyiv, Ukraine. https://orcid.org/0000-0002-9000-7358

Bielozorova O.V. A,C,D,E,F - Lieutenant Colonel of the Medical Service, Candidate of Pharmaceutical Sciences, Head of the Scientific and Organizational Department of the Ukrainian Military Medical Academy, Kyiv, Ukraine. https://orcid.org/0000-0001-7257-3965

Nikityuk A.V. ${ }^{B, C}$ - senior lieutenant of the medical service, Head of the medical supply department of 71 military mobile hospitals, Kyiv, Ukraine.

Адреса для листування: вул. Московська, 45/1, буд. 33, м. Київ, 01015. 